\title{
Persistent hyperinsulinemic hypoglycemic in infant: a case report
}

\author{
Nur Rochmah*, Muhammad Faizi \\ From 8th APPES Biennial Scientific Meeting \\ Darwin, Australia. 29 October - 1 November 2014
}

Persistent hyperinsulinemic hypoglycemic in infant is risk factor for impairment during brain development process. Early diagnosis and treatment will result in better outcome. The aim is to report a case of persistent hyperinsulinemic hypoglycaemic infant. Methode is case report. A, 2 days old term infant, was referred due to hypoglicemia. He got generalized seizure and recurrent hypoglicemia. He can drink well. No vomiting observed. The Apgar score was 6-7-8. Birth weight was 4000 gram. He was the third child. Second child had the same history. No history of diabetes mellitus in the family. Physical examination revealed normal limit. Laboratory examination showed $\mathrm{Hb} 16.8 \mathrm{gram} / \mathrm{dl}$, WBC17.4/cmm; hematocrite $50.1 \%$; platelet $316 / \mathrm{cmm}$; blood glucose $105 \mathrm{gram} / \mathrm{dl}$, potassium $4.6 \mathrm{mmol} / \mathrm{l}$, sodium $139 \mathrm{mmol} / \mathrm{l}$, chloride $106 \mathrm{mmol} / \mathrm{l}$, calsium $9.6 \mathrm{mg} / \mathrm{dl}$, BUN $5.1 \mathrm{mg} / \mathrm{dl}$, creatinin serum $0.82 \mathrm{mg} / \mathrm{dl}$, Direct Bilirubin $0.079 \mathrm{mg} / \mathrm{dl}$, Total bilirubin $0.19 \mathrm{mg} / \mathrm{dl}$, SGOT 16 U/L, SGPT 10 U/L, CRP 11.10 mg/dl. During hypoglycaemia we got the result as follows: growth hormon $2.99 \mathrm{ng} / \mathrm{ml}(0.06-5)$, cortisol serum $198 \mathrm{ng} / \mathrm{ml}$ (50-250), fasting Insulin $10.30 \mathrm{Uu} / \mathrm{ml}$ (2.6-24.9). Head ultrasonography revealed normal. The patient was given IVFD Dextrose $100.18 \%$ saline (glucose infusion rate 4-5 $\mathrm{mg} / \mathrm{kg} / \mathrm{min}$ ), breast milk $8 \times 30-60 \mathrm{cc}$, Ocreotide $5 \mathrm{mcg} / \mathrm{kg} /$ day iv, Nifedipin $4 \mathrm{x}$ 0.5-2.5mg per oral. Bolus $2 \mathrm{cc} / \mathrm{kg}$ body weight of D10\% if the blood sugar level was low. Hypoglycemic improved after treatment. As conclusion we should be aware of hypoglycemia in infant, it may due to persistent hyperinsulinism hypoglycemia of infant in which careful management is needed.

Written informed consent was obtained from each patient's parent or guardian for publication of this abstract and any accompanying images. A copy of the

Faculty of Medicine-Airlangga University-dr Soetomo Hospital, Surabaya, East Java, Indonesia

C 2015 Rochmah and Faizi; licensee BioMed Central Ltd. This is an Open Access article distributed under the terms of the Creative Commons Attribution License (http://creativecommons.org/licenses/by/4.0), which permits unrestricted use, distribution, and reproduction in any medium, provided the original work is properly cited. The Creative Commons Public Domain Dedication waiver (http://creativecommons.org/publicdomain/zero/1.0/) applies to the data made available in this article, unless otherwise stated. 